\title{
SLC18A1 Gene
}

National Cancer Institute

\section{Source}

National Cancer Institute. SLC18A1 Gene. NCI Thesaurus. Code C107577.

This gene is involved in the transport of biogenic monoamines. 